\title{
Wall Paper Editions of the Daily Citizen, Vicksburg, Miss.
}

Library of Congress Periodical Division, Washington, D.C.

The Daily Citizen was edited and published at Vicksburg, Miss., by J. M. Swords. Like several other southern newspapers of the Civil War period its stock of newsprint paper became exhausted and the publisher resorted to the use of wall paper. On this substitute he printed the following known issues: June 16, 18, 20, 27, 30 and July 2, 1863. Each was a single sheet four columns wide printed on the back of the wall paper.

On July 4 Vicksburg surrendered, the publisher fled, and the Union forces found the type of the Citizen still standing. They replaced two-thirds of the last column with other matter already in type, added the now famous Note of July 4 at the end and printed a new edition.

\section{Note.}

July 4 th, 1863.

Two days bring about great changes. The banner of the Union floats over Vicksburg. Gen. Grant has "caught the rabbit;" he has dined in Vicksburg, and he did bring his dinner with him. The "Citizen" lives to see it. For the last time it appears on "Wall-paper." No more will it eulogize the luxury of mule-meat and fricassed kitten-urge Southern warriors to such diet never-more. This is the last wall-paper edition, and is, excepting this note, from the types as we found them. It will be valuable hereafter as a curiosity.

The prophecy contained in the Note has been fulfilled. The original copies are treasured and there have been over thirty reprints of this issue. The genuine originals can be distinguished by the following tests:

1. Single type page, $9 \frac{1}{8}$ inches in width by $167 / 8$ inches in length.

2. Column 1, line 1, title THE DAILY CITIZEN, in capitals, not capitals and lower case, or capitals and small capitals.

3. Column 1, line 2, "J. M. Swords, ...... Proprietor." Notice the comma (or imperfect dot) and six periods. 
4. Column 1, last line, reads: "them as they would the portals of hell itself."

5. Column 3, line 1, reads: "Yankee News From All Points."

6. Column 4, line 1 reads: "tremity of the city. These will be defended."

7. Column 4, paragraph 3 , line 7 , first word is misspelled "Secossion."

8. Column 4, article 2, line 2, word 4 is spelled "whisttle."

9. Column 4, last article before Note, final word is printed with the quotation misplaced, 'dead' instead of dead."

Another method of selecting the originals is through the designs of the wall paper used. Only three such have been found and none of the reprints duplicate or even resemble these:

1. A large brocade pattern in faded red-purple over a scroll design in faded rose on a cream background.

2. A design of white three-lobed, palmate leaves placed close together with small flowers and leaflets, like veins, in the center of each, all partly outlined with heavy dark blue.

3. Small flowers with connecting vines giving the effect of a diamond-latticed trellis; leaves, flower-petals and stems in faded yellow-green on a cream background, centers of flowers dark brown.

U.S. Government Printing Office: 1936

\section{Editor's Note...}

For several years these "wall paper editions" have been turning up and most of them have proved to be copies. There are only three known originals. One, at least, is in the Library of Congress, Washington, D. C. Validity of any of these unusual newspaper editions can be checked by the above which was issued by the Library of Congress. 
Copyright of Annals of Iowa is the property of State of Iowa, by \& through the State Historical Society of Iowa and its content may not be copied or emailed to multiple sites or posted to a listserv without the copyright holder's express written permission. However, users may print, download, or email articles for individual use. 